\title{
Maria Ujwary
}

Jesuit University Ignatianum in Cracow

Faculty of Philosophy

e-mail: maria.ujwary@gmail.com

\section{Założenia etyczne Kodeksu Etyki Żywnościowej}

\section{Ethical assumptions of the Food Ethics Code}

The main point of the article is to analyze the ethical assumptions of the Codex of Food Ethics and to answer the question of whether the formalization of morality related to food is possible at all. The analyzed Codex was created in October 2013, with the participation of experts from various communities. The value that was indicated and considered to be accepted by all acceding to its use is the "good of the consumer," although it was not clearly defined in the content of the Code. The Code does draw attention to safety, quality, trust, control, and respect of the law, however. These issues were discussed in the article. Unfortunately, due to the lack of information about the further fate of the Code, it is difficult to answer the question whether it has a chance to for practical application in the form proposed by its creators.

Keywords: food, food safety, food ethics, Code of Ethics

JEL Classification: Q180

\section{Wprowadzenie}

Niewiele rzeczy łączy ludzi na świecie tak, jak żywność. Żywność to życie i bezpieczeństwo. Zależy od niej zdrowie i przetrwanie człowieka. Dostęp do niej nie jest i nie był równy w żadnym zakątku naszej planety. Współczesny świat cechują skrajności - od niedostatku po nadprodukcję. Żywność jest marnowana, a to, co jest produkowane i trafia na nasz stół, podlega modzie, opiniom ekspertów i cią- 
głym modyfikacjom. Głosy, by troski o żywność nie lekceważyć, są coraz częstsze. Wobec ujawnianych przypadków niezgodnego z prawem bądź nieetycznego zachowania producentów żywności, stają się one krzykiem, domagającym się poszanowania żywności oraz konsumentów.

Na początku 2012 roku wybuchła w Polsce tzw. afera solna, a zaraz po niej afera $\mathrm{z}$ podrabianym suszem jajecznym. Zawiodły organy kontrolne, które powinny zapewnić nadzór nad bezpieczeństwem, ale rozczarowała również etyka, która wśród nieuczciwych producentów przegrała $\mathrm{z}$ rachunkiem ekonomicznym. Pojawiły się głosy o potrzebie stworzenia w Polsce Kodeksu Etyki Żywnościowej. Powstał on w październiku 2013 roku (Powstał Kodeks..., 2013, s. 82-83).

W artykule przybliżona zostanie treść kodeksu oraz przeanalizowane będą wartości etyczne, które stały się punktem wyjścia dla jego twórców. Celem jest odpowiedź na pytanie, czy formalizacja zagadnień moralnych w kontekście żywności jest możliwa.

Od czasu powstania kodeksu trudno o jakiekolwiek wzmianki dotyczące jego funkcjonowania. Najszerzej odnosi się do niego publikacja Etos polskich przetwórców żywności (Wysocki \& Zarzecki, 2016, s. 12). Autorzy informują o motywach powstania kodeksu oraz załączają jego treść jako aneks do publikacji. Założenia kodeksu nigdzie nie zostały jednak poddane szczegółowej analizie, co ma być celem niniejszego artykułu. Jest to tym bardziej godne uwagi, że w ostatnim czasie konsumentami wstrząsnęła kolejna afera dotycząca żywności (Chore krowy..., 2019). $\mathrm{W}$ jej kontekście ponownie zadawane są pytania o miejsce etyki. W mediach pojawiła się również informacja o podjęciu działań w kierunku stworzenia Kodeksu Etyki Zawodowej Rolnika i Producenta Żywności (List otwarty..., 2019).

\section{Geneza powstania kodeksu}

Rok poprzedzający powstanie Kodeksu Etyki Żywnościowej obfitował w afery związane z produkcją żywności. Dyskusja w branży spożywczej, ale również na łamach ogólnopolskich mediów dotyczyła organów kontroli, które być może zawiodły, ale także etyki, która powinna stać przed rachunkiem ekonomicznym. Pismo Bezpieczeństwo i Higiena Żywności włączyło się w tę dyskusję szczególnie mocno. Ówczesny redaktor naczelny Tadeusz Wojciechowski $(2012$, s. 10) pisał na jego łamach:

Mimo że organizacje producenckie kokieteryjnie nazywają konsumenta „królem", próbują nim manipulować i stawiają zawsze swój interes na pierwszym planie. Jest więc potrzebą chwili wypracowanie Kodeksu Etyki Przemysłu Żywnościowego odwołującego się do nauki Jana Pawła II, ponieważ, jak widać, samo prawo nie wystarczy.

Przygotowaniem kodeksu zajęła się grupa specjalistów z różnych dziedzin. Inicjatywa powołania tej grupy powstała przy delegacie Konferencji Episkopatu Polski ds. Duszpasterstwa Polskich Przetwórców Żywności. Był nim wówczas 
ks. bp. Tadeusz Pikus (Wysocki \& Zarzecki, 2016, s. 12). Koordynatorem zespołu był prof. Janusz B. Berdowski, przewodniczący Sekcji Przemysłu Spożywczego Polskiego Forum ISO 9000. Z jego podziękowania podsumowującego powstanie kodeksu dowiadujemy się, że dyskusjom poddane były dwa robocze projekty przygotowane przez Andrzeja Gantnera i Grzegorza Trochimczuka (Powstat Kodeks..., 2013, s. 83). Skład zespołu ekspertów opracowujących dokument został przedstawiony we wprowadzeniu do niego. Znaleźli się w nim przedstawiciele środowisk akademickich zajmujących się żywnością, producentów żywności, osoby zajmujące się jakością oraz duszpasterze, którzy wspierają reprezentantów sektora związanego z gospodarką. Uznać można, że eksperci ci dysponowali szerokim spektrum wiedzy, doświadczeniem i zapewne różnymi punktami widzenia. Daje to nadzieję, że Kodeks Etyki Żywnościowej jest pełny ${ }^{1}$. Jednak czy to wystarczy? Czy ogromną złożoność etycznych problemów związanych z żywnością da się zamknąć się w kodeksie?

Pytanie to wiąże się o toczącą się od dawna dyskusją nad skutecznością i zasadnością instytucjonalizacji moralności. Uzasadnione wydaje się przytoczenie w tym miejscu słów Leszka Kołakowskiego (1967, s. 153) dotyczących kodyfikacji:

Żaden kodeks nie jest naprawdę ostatecznie wyczerpujący, jednakże idea kodeksu zawiera w sobie dążność stałą do uzyskania ideału kompletności, a więc do takiego zbioru reguł, które dają się zastosować do dowolnej sytuacji moralnej i zawsze ją przesądzają jednoznacznie. Ideał kodeksu to ideał doskonale rozstrzygalnego systemu, z którego, w połączeniu z opisem sytuacji, da się wydedukować dowolny sąd wartościujący lub jego negację.

Po analizie kodeksu, w podsumowaniu, odniosę się do tego poglądu. Przytaczam go również dlatego, że w mojej ocenie w informacji poprzedzającej treść kodeksu jego autorzy już się do niego odnoszą. Do odbiorcy dokumentu kierują następujące słowa:

Ze względu na fakt, że adresatem kodeksu mają być wszyscy pracownicy zatrudnieni w tej sferze, postanowiono, aby jego treść była zwięzła i ujmowała jedynie najważniejsze wskazania etyczne w tym zakresie. Wskazania te będą punktem odniesienia do właściwych konkretnych wyborów i działań wszystkich producentów żywności, mających na względzie dobro i zdrowie konsumenta żywności. (Kodeks Etyki Żywnościowej, 2013, s. 4)

Czyżby już z chwilą oddania kodeksu jego niewyczerpalność była jego twórcom znana? Czy wynika to ze świadomości złożoności zjawisk dotyczących żywności oraz ich ciągłej ewolucji? Przyjrzyjmy się tym najważniejszym „wskazaniom etycznym".

\footnotetext{
${ }^{1}$ Skład zespołu specjalistów: ks. bp prof. dr. hab. Tadeusz Pikus, mgr Krzysztof Ardanowski, prof. nadzw. dr inż. Janusz Bronisław Berdowski, mgr inż. Łukasz Chmiel, mgr inż. Andrzej Gantner, mgr Andrzej Kiszczak, mgr inż. Stefan Kwiecien, dr hab. Irena Ozimek, ks. mgr lic. Michał Szwemin, mgr Grzegorz Trochimczuk, mgr Tadeusz Wojciechowski, ks. dr Artur Wysocki, inż. Jan Tadeusz Woźniak.
} 
Kodeks składa się z dwóch wyodrębnionych działów -,Wstępu” oraz „Zaleceń szczegółowych" ". Wstęp jest swoistą preambułą, przytoczone są w nim wartości, których szersze omówienie znajdziemy w dalszej części. Dowiadujemy się z niego również, że wskazaną i akceptowaną przez wszystkich przystępujących do stosowania zasad kodeksu wartością podstawową jest „dobro konsumenta”. Po analizie kodeksu chciałabym również znaleźć odpowiedź na pytanie, czym jest „dobro konsumenta” w rozumieniu jego autorów.

\section{Zalecenia szczególowe}

\section{Bezpieczeństwo i jakość żywności}

W zaleceniach szczegółowych odnajdziemy nieco szersze, bardziej wyczerpujące omówienie elementów wstępu. Punkt pierwszy poświęcony jest bezpieczeństwu: „Bezpieczeństwo i jakość” żywności są wartościami nadrzędnymi w prowadzeniu i rozwijaniu biznesu żywnościowego (Kodeks Etyki Żywnościowej, 2013, s. 7). Trudno tej wartości odmówić pierwszeństwa. Poczucie bezpieczeństwa w każdym wymiarze jest dla człowieka niezmiernie ważne.

Przyjrzyjmy się bliżej, co oznacza bezpieczeństwo, gdy mówimy o żywności. To nie tylko jej dostępność w sensie fizycznym i ekonomicznym, ale także bezpieczeństwo zdrowotne (Niklińska \& Woronowski, 2014, s. 161). Przez konsumentów oczekiwane i wymagane jest, że to, co spożywają, jest dla nich bezpieczne i nie spowoduje uszczerbku na zdrowiu. Rzeczywistość niestety coraz częściej rozmija się z naszymi wcale niewygórowanymi oczekiwaniami. Media regularnie informują o nieprawidłowościach w związku z jakością dostarczanej na rynek żywności. Przytoczyć należy wspomniane we wstępie afery związane z dodawaniem soli drogowej do żywności, sfałszowanym suszem jajecznym, koniną wykrytą w mięsie wołowym (Pieńczykowska, 2013) oraz sprawę dotyczącą uboju chorych zwierząt, których mięso trafiało na stoły (Chore krowy..., 2019). Wszystkie te działania były jednoznacznie nieetyczne.

Wśród najczęściej stosowanych współcześnie praktyk fałszowania żywności wymienia się: zaniżanie zawartości wartościowych składników, zastępowanie składników droższych tańszymi, nieujawnianie konsumentom składników małowartościowych, stosowanie niedozwolonych praktyk marketingowych, podawanie w wykazie składników tych, których w produkcie nie ma (Kowalczyk, 2014, s. 151). Kodeks Etyki Żywnościowej w punkcie dotyczącym bezpieczeństwa stara się odnieść do tych powszechnie stosowanych działań. Przede wszystkim zwraca uwagę, że najistotniejsze dla zagwarantowania bezpieczeństwa i jakości jest przestrzeganie prawa żywnościowego.

Wyodrębnienie prawa żywnościowego to zjawisko dość współczesne. Troska o żywność to również troska o zdrowie i życie ludzi, dlatego wymaga szczególne-

\footnotetext{
${ }^{2}$ Zalecenia szczegółowe w kodeksie zostały ujęte przez jego twórców w odniesieniu szerszym, bardziej obszarowym, np. uczciwość, która powinna być uwzględniona we wszystkich relacjach rynkowych.
} 
go systemu ochrony (Korzycka \& Wojciechowski, 2016, s. 277), dlatego jako działanie nieetyczne wymienione zostaje ,produkowanie żywności w sposób niezgodny z prawem na jakimkolwiek etapie" (Kodeks Etyki Żywnościowej, 2013, s. 7). Ponadto autorzy kodeksu zwracają uwagę na obowiązek ochrony wartości odżywczych. Ma to być spełnione przez odpowiedni dobór „technologii, technik, aparatury, środków” (Kodeks Etyki Żywnościowej, 2013, s. 8). Ostatni punkt z zakresu bezpieczeństwa poświecono wszelkim praktykom fałszowania. Uznane są one za „niedopuszczalne, a za jednoznacznie nieetyczne uznaje się świadome stosowanie surowców niewiadomego pochodzenia, zafałszowanych lub oferowanych poza oficjalnym obrotem" (Kodeks Etyki Żywnościowej, 2013, s. 8).

Kodeks zarówno w tym punkcie, jak i dotyczącym zaufania uznaje za słuszną i skuteczną dla stosowania etycznych norm postępowania ideę solidaryzmu. Autorzy zwracają uwagę, że niezwykle istotne jest wspólne, solidarne działanie zmierzające do eliminowania przypadków zafałszowań. Co więcej, sytuacje, które zostaną wykryte, powinny być zgłaszane właściwym służbom (Kodeks Etyki Żywnościowej, 2013, s. 8). O organach kontroli wspomnę w dalszej części artykułu.

\section{Minimalizowanie strat}

Punkt drugi Kodeksu Etyki Żywnościowej zwraca uwagę na kolejne ważne zagadnienie. Jego tytuł brzmi: „Żywność to dobro wymagające poszanowania poprzez minimalizowanie strat na każdym etapie łańcucha żywnościowego". Autorzy skupiają $\mathrm{w}$ nim uwagę na potrzebie racjonalnego wykorzystania żywności i niemarnowania jej. Temat ten jest medialnie chyba bardziej popularny niż bezpieczeństwo żywności. Kwestia bezpieczeństwa powraca $\mathrm{z}$ chwilą ujawnienia kolejnej afery związanej z fałszowaniem żywności i oszukiwaniem konsumentów, natomiast temat niemarnowania jest stały. Wzmożone zainteresowanie tym zagadnieniem zauważamy może w okresie przed- i poświątecznym, gdy konsumenci wpadają w wir zakupów. Należy jednak zwrócić uwagę, że bardziej eksponowany jest problem marnowania żywności przez konsumentów właśnie. Takie etapy łańcucha żywnościowego, jak producenci i przetwórcy, nieco giną. Kodeks natomiast stawia nacisk na konieczność minimalizowania strat i taki sam nacisk kładzie na każdy etap łańcucha żywnościowego. Zakresem obejmuje nie tylko straty produktów, ale także „składników i wartości odżywczych” (Kodeks Etyki Żywnościowej, 2013, s. 8).

Żywność to dobro, a mimo to na wielką skalę go nie szanujemy. Według najnowszych badań na świecie marnuje się 1,3 mld ton żywności rocznie, z czego $88 \mathrm{mln}$ ton w Unii Europejskiej (Raport FPBŻ, 2018, s. 4). Największą grupą marnujących są konsumenci oraz przetwórcy. Najnowsze krajowe dane dotyczące zjawiska marnowania żywności pochodzą niestety sprzed 12 lat. Według nich w Polsce marnowało się rocznie $9 \mathrm{mln}$ ton jedzenia. Federacja Polskich Banków Żywności rozpoczęła nowy projekt „EkoMisja Nie Marnuję”, którego jednym z założeń jest przeprowadzenie nowych badań. Będzie można dzięki nim uzyskać informacje, które etapy łańcucha żywnościowego generują największe straty. 
Marek Borowski, prezes Federacji Polskich Banków Żywności, twierdzi:

Temat marnowania żywności to wciąż temat tabu, w kontekście którego czujemy pewien rodzaj wstydu. Wiemy, że wyrzucać nie powinniśmy, że robimy źle, ciężej nam jest się również do tego przyznać. (Raport FPBŻ, 2018, s. 6)

Do marnowania dobra, jakim jest żywność, przyznaje się 42\% Polaków (Raport FPBŻ, 2018, s. 6). W celu eliminacji tych nieetycznych zachowań podejmowane są różne działania. Różne organizacje prowadzą warsztaty kulinarne, wydawane są książki, z których dowiemy się, jak wykorzystać produkty żywnościowe, na które brakło nam pomysłów kulinarnych. Prowadzone są akcje edukacyjne na temat tego, jak przechowywać jedzenie, by dłużej zachowało świeżość, byśmy nie wychodzili na zakupy bez listy potrzebnych nam produktów. Jednak, jak również podkreślono w raporcie, drogi do zmiany niechlubnych nawyków są dla poszczególnych konsumentów różne ${ }^{3}$. Wspomnieć można choćby głośną medialnie akcję Banków Żywności „Kupuj samotne banany. Chroń przed zmarnowaniem” (Kupuj samotne banany..., 2018). Konsumenci chętniej wybierają kiść bananów, skazując na zmarnowanie pojedyncze sztuki, które zwykle są pełnowartościowe. Akcja stała się popularna w całej Polsce, przyłączyła się do niej jedna z sieci handlowych, a wielu kupujących nie omija już pojedynczych owoców. Minimalizowanie strat jest przecież według kodeksu istotne dla „każdego podmiotu gospodarczego" (Kodeks Etyki Żywnościowej, 2013, s. 8).

Nie zapominajmy również, że wyrzucanie jedzenia to postawa nieetyczna także ze względu na negatywne skutki naszego działania na środowisko, np. „wyrzucona kanapka z serem to aż 90 litrów zmarnowanej wody" (Raport FPBŻ, 2018, s. 4).

\section{Zaufanie}

Kwestia zaufania konsumentów została podkreślona w Kodeksie Etyki Żywnościowej jako niezmiernie istotna. Punkt trzeci brzmi: „Zaufanie konsumentów podlega solidarnej ochronie przez wszystkich uczestników łańcucha żywnościowego" (Kodeks Etyki Żywnościowej, 2013, s. 8). W rozwinięciu tego punktu odnajdujemy nawołanie do jednoznacznego eliminowania przypadków naruszenia zaufania konsumentów przez nieuczciwe praktyki i nieetyczne działania.

Dokonując codziennych zakupów, biorąc z półki jakikolwiek produkt żywnościowy, obdarzamy jego producenta zaufaniem. Wspomniane wcześniej, ujawnione przez media afery dotyczące fałszowania żywności mocno nadwyrężają zaufanie. Do czego w tym zakresie zobowiązuje nas kodeks? Ponownie podnosi wartość solidaryzmu, także w kwestii zaufania. Zaufanie konsumentów podlega solidarnej ochronie, podobnie jak ,dobre imię i wizerunek produkowanej w Polsce żywności”. Solidarnie powinniśmy eliminować i potępiać wszelkie nieetyczne zachowania naruszające zaufanie (Kodeks Etyki Żywnościowej, 2013, s. 8). Oprócz wspomnianego potępienia takich zachowań, zgodnie z kodeksem, powin-

\footnotetext{
${ }^{3}$ Sprawę skomentował w omawianym raporcie Tomasz Sobierajski (Raport FPBŻ, 2018, s. 14).
} 
niśmy podejmować działania polegające na eliminowaniu nieuczciwych podmiotów z rynku, zgłaszając te działania odpowiednim organom kontrolnym. Ponownie kodeks wspomina też o organach kontroli jako narzędziu powołanym do egzekwowania wykonalności zasad.

\section{Rzetelna informacja}

Nikt z nas nie chce być oszukiwany, a rzetelność kierowanej do konsumentów informacji jest niezmiernie ważna. Chcemy wiedzieć, co jemy i za co płacimy. Jest to podejście świadomego konsumenta, który dba o swoje zdrowie i bezpieczeństwo. Kodeks Etyki Żywnościowej odnosi się do tego zagadnienia. Trudno nie uwzględnić jako działania nieetycznego świadomego wprowadzania konsumentów w błąd. Możliwości takiego działania jest wiele, to np. błędne znakowanie czy sugestywna reklama (Kodeks Etyki Żywnościowej, 2013, s. 9). W kwestii reklamy dokument odsyła nas do Kodeksu Etyki Reklamy.

Problem odpowiedniego oznakowania produktów jest szczegółowo uregulowany prawnie (Podstawowe wymagania..., 2018). W świetle Kodeksu Etyki Żywnościowej zwraca się uwagę na zależność oznakowania produktów i dokonywane przez konsumentów wybory. Zamieszczone na opakowaniu dane stanowią pierwsze źródło informacji, np. o składnikach czy sposobie przygotowania. W wielu przypadkach od tej informacji zależy nasze zdrowie i życie, np. od danych o substancjach i produktach wywołujących alergie bądź nietolerancje.

Jest to także kolejny punkt kodeksu, z którego - być może nie wprost - odczytujemy odwołanie się do wartości bezpieczeństwa i zaufania. Jako przykład podać można rolnictwo ekologiczne, gdzie oznaczenie unijnym logo i odpowiednie etykietowanie daje konsumentowi poczucie, że kupuje produkt o wysokim standardzie. Badania pokazują, że 70\% Europejczyków ma zaufanie do produktów ekologicznych (Rolnictwo ekologiczne w skrócie).

\section{Kodeks Etyki Reklamy}

Kodeks Etyki Żywnościowej w czwartym i piątym punkcie odsyła do Kodeksu Etyki Reklamy. W nim znajdziemy szczegółowe wymagania, jakie powinna spełniać reklama żywności, oraz informacje o traktowaniu dzieci do lat 12 jako konsumentów. Kodeks podkreśla, że szczególne traktowanie dzieci wynika z ich „niepełnej możliwości oceny wartości i jakości poszczególnych produktów” (Kodeks Etyki Żywnościowej, 2013, s. 9).

Na stronie internetowej Rady Reklamy znajdują się szczegółowe informacje odnoszące się do tych regulacji. W myśl Kodeksu Etyki Reklamy Załącznik nr 2, Standardy Reklamy Żywności skierowanej do dzieci są następujące: „Reklama produktów żywnościowych nie może być kierowana bezpośrednio do dzieci, które nie ukończyły 12. roku życia". Dalsze artykuły załącznika w sposób szczegółowy rozwijają zagadnienie. Istotne jest, że integralnym załącznikiem do Kodeksu Etyki Reklamy są „Kryteria Żywieniowe do samoregulacji dotyczącej reklamy żywności skierowanej do dzieci w wieku poniżej 12. roku życia w Polsce”. Dokument ten, 
opracowany przez Polską Federację Producentów Żywności Związek Pracodawców, zaakceptowany przez Instytut Żywności i Żywienia, powstał m.in. „w celu doprecyzowania kryteriów, według których produkty żywnościowe będą mogły być reklamowane do dzieci do lat 12". Celem pracy nie jest analizowanie Kodeksu Etyki Reklamy ani Załączników nr 2 i 2a, należy jednak zwrócić uwagę, że kwestie żywieniowe w stosunku do dzieci od dawna nie są etycznie obojętne. Krzepiące jest to, że chęć zysku schodzi na drugi plan, a troska o wychowanie młodego pokolenia jest sprawą istotną (Wysocki, 2016, s. 61). Wyrobienie u młodego pokolenia odpowiednich nawyków żywieniowych będzie skutkowało świadomymi wyborami w przyszłości, a więc dbałością o zdrowie. Takie mocno utylitarne podejście do zagadnienia to wyraz odpowiedzialności.

\section{Uczciwość w konkurowaniu}

Uczciwość - wielokrotnie podkreślana w kodeksie - w głównej mierze dotyczy postawy wszystkich podmiotów gospodarczych wobec konsumentów. Punkt szósty Kodeksu Etyki Żywnościowej stawia wymagania etyczne wszystkim uczestnikom rynku wobec siebie. Przestrzeganie zasad etycznych w relacjach rynkowych zdaję się niezwykle trudne, w grę wchodzi przecież osiągnięcie określonych zysków. Produkcja, przetwórstwo czy obrót żywnościową to biznes, zatem dla poszczególnych podmiotów istotny jest zysk.

Zrozumiałe jest, że podmioty oferujące konsumentom dobro, jakim jest żywność, konkurują z sobą. Pożądane jest, by w tym konkurowaniu nie zwyciężyły względy ekonomiczne, a zasady etyczne nie zostały pominięte bądź potraktowane wybiórczo.

Co według kodeksu jest zachowaniem etycznym, które przy podejmowaniu decyzji trzeba uwzględniać na równi z przestrzeganiem przepisów prawa? Należy klientów i dostawców traktować z szacunkiem, nie faworyzując nikogo. Nie powinno się stosować zabiegów dyskredytujących konkurencję, nie należy tworzyć porozumień z konkurentami w celu ustalania cen lub innych uzgodnień dotyczących sprzedaży (Kodeks Etyki Żywnościowej, 2013, s. 10). W mojej opinii zdecydowanie lepszą i trwalszą metodą przyciągnięcia klientów będzie zapewnienie im produktów odpowiedniej jakości, przedstawienie rzetelnej informacji o produkcie i utrzymanie zaufania przez ciągłe podtrzymywanie wysokich standardów.

Korzyści ekonomiczne zostały również podkreślone w punkcie dotyczącym bezpieczeństwa. Pokusa szybkiego zysku jest zapewne silna, ale nie do przyjęcia kosztem lekceważenia zasad etycznych i przepisów prawa. Naraża to konsumenta na utratę zdrowia, a nawet życia.

\section{Respektowanie urzędowej kontroli żywności}

Zagadnienie urzędowej kontroli pojawiło się już wcześniej. Zgłaszanie nieuczciwych praktyk odpowiednim organom kontroli jest według kodeksu sposobem walki z nieetycznymi działaniami. Właściwie przeprowadzona i skuteczna urzędowa kontrola daje konsumentom większe poczucie bezpieczeństwa. Niestety 
wykrywane afery, gdy konsument jest oszukiwany, stawia pytania o skuteczność organów kontrolnych i podważa zaufanie do nich. Receptą na takie sytuacje są więc odpowiednie relacje „wszystkich podmiotów łańcucha żywnościowego z organami urzędowej kontroli żywności” (Kodeks Etyki Żywnościowej, 2013, s. 10). Nie zapominajmy, że konsument to też „organ” kontroli. Jeśli jakiś producent straci zaufanie klientów, to poniesie konsekwencje ekonomiczne w postaci utraty zysków.

W badaniu „Etos polskich przetwórców żywności 2016” zapytano ankietowanych, czy uważają, że należy zawsze zgłaszać przypadki niezgodnego z przepisami postępowania przetwórców żywności odpowiednim organom kontroli (Linek, 2016, s. 201-203). 76,7\% respondentów odpowiedziało, że raczej tak, $17,2 \%$ - zdecydowanie tak. Daje to poczucie, że istnieje wysoka świadomość tego, iż ewentualne działania w celu zgłoszenia nieprawidłowości nie są pozbawione skuteczności i mają znaczący wpływ na bezpieczeństwo.

\section{Wnioski}

Dyskusja wokół tworzenia kodeksów etycznych jest żywa i z pewnością powstanie Kodeksu Etyki Żywnościowej się w nią wpisuje. Żywność to dobro, które łączy wszystkich ludzi i w istotny sposób wpływa na ich relacje. Wszelkie ingerencje w jej dostępność, jakość, skład, bezpieczeństwo stają się oddziaływaniem na sferę godności człowieka. Zastanowić się należy, czy tak delikatnej, a zarazem odpowiedzialnej i bardzo ważnej, bo wpływającej na zdrowie i życie człowieka, sferze żywności i żywienia sprostał Kodeks Etyki Żywnościowej.

Dużym plusem tego dokumentu jest zaangażowanie w jego powstanie ekspertów reprezentujących różne środowiska związane z żywnością. Nie dotarłam do źródeł, które mówiłby o tym, czy treść kodeksu była przedmiotem burzliwych dyskusji. Jednak z informacji wstępnych do kodeksu, w których przedstawiono sylwetki jego twórców, można wnioskować, że nad zagadnieniem pochylili się ludzie, którzy znają je z różnych perspektyw. Na poparcie takiej argumentacji przytoczę cytat z książki Roberta Spaemanna Granice (2006, s. 40):

Etyka stosowana powinna być zawsze związana z określoną dziedziną - na przykład z medycyną czy gospodarką - i powinna być rozwijana w ścisłej współpracy z odpowiednimi wydziałami i z ludźmi należącymi do tej grupy zawodowej, której etos jest przedmiotem namysłu. Zazwyczaj będą to nie tylko ci ludzie, którzy mają odpowiednią wiedzę w danej materii, lecz przede wszystkim ludzie żyjący etosem, który jest właściwy dla danego zawodu. Ludzie zajmujący się wyłącznie filozofią mogą być tu - jako wolni od zobowiązań intelektualiści - bardzo niebezpieczni. Jako pacjent chętniej zaufam każdemu przeciętnemu lekarzowi niż lekarzowi, który w krytycznym momencie uzależnia swój sąd od decyzji komisji etycznej, której ton nadaje radykalny utylitarysta. 
Omawiany dokument w sposób jasny definiuje zachowania nieetyczne. Szczególnie mocno piętnuje je we wstępie, tworząc ich listę, oraz w punkcie dotyczącym bezpieczeństwa i jakości żywności. W innych punktach nie jest to już tak szczegółowo omówione.

Z całą pewnością wśród wskazanych w kodeksie wartości etycznych znajdują się takie o znamionach utylitarnych. Słuszność ich przestrzegania nastawiona jest nie tylko na teraźniejszość, ale również na skutki w przyszłości. Wyodrębnione w kodeksie wartości wyróżniają konsekwencjalizm i orientacja na przyszłość.

$\mathrm{W}$ dokumencie tym nie mamy jednak bezpośredniego odwołania do sankcji. Znając specyfikę problematyki, jaką ujmuje kodeks, oraz próbę objęcia nim większości podmiotów łańcucha żywnościowego, jest to usprawiedliwione działanie. Nie można powiedzieć jednak, że zostało to zupełnie pominięte. Prawie w każdym punkcie znajduje się odwołanie do konieczności stosowania się do przepisów prawa żywnościowego oraz zgłaszania naruszeń do odpowiednich organów kontrolnych. Można zatem wnioskować, że ewentualne sankcje są istotne, ale leżą w gestii kolejnych podmiotów. We wstępie jest natomiast wzmianka o innych formach sankcji, do których należą: ,podleganie ocenie, napiętnowaniu i eliminacji przez samych uczestników działających w gospodarce żywnościowej” (Kodeks Etyki Żywnościowej, 2013, s. 7). Dalsza część kodeksu tych form sankcji nie rozwija.

Do dyskusji pozostaje kwestia, czy kodeks nie powinien w początkowym punkcie usystematyzować i wyjaśnić najistotniejszych użytych w teksie pojęć. Byłoby to uzasadnione np. w przypadków wspomnianych wyżej organów kontrolnych.

Kodeks Etyki Żywnościowej przy ewentualnym pełnym działaniu ma objąć wszystkich uczestników łańcucha żywnościowego „od pola do stołu”. I chociaż wskazuje liczne wartości, które powinny stać u podstaw ich etycznego działania, to $\mathrm{w}$ mojej ocenie zbyt mało wybrzmiewa w nim odpowiedzialność. Być może odpowiedzialność moralna została rozbita na części w postaci omawianych zaleceń szczegółowych, ale czy wstęp nie powinien odwoływać się w sposób stanowczy do poczucia odpowiedzialności? Podnieść tu należy odpowiedzialności wszystkich podmiotów za przyszłe pokolenia.

Odpowiedzialność za jutrzejsze pokolenia jest prastarym problemem ludzkości. Zagadnienie to było dostrzegane od tysiącleci i nie była do tego potrzebna jakaś specjalna etyka odpowiedzialności za przyszłość. Normy odpowiedzialności za czasy nadchodzące były wewnętrznie przestrzegane i przekazywane wraz z innymi normami kulturowymi, po części jako element ogólnego zwyczaju lub religijnej tradycji, po części jako składnik etosu określonych stanów, grup zawodowych i instytucji. (Birnbacher, 1999, s. 3)

Powyższy cytat odnosi się do znaczenia odpowiedzialności za przyszłe pokolenia, do jej oczywistości. Chociaż autor tych słów podkreśla, że ta oczywistość nie potrzebowała specjalnej etyki, to skoro Kodeks Etyki Żywnościowej powstał, powinniśmy go wykorzystać jako nośnik tego przesłania. Modyfikacja żywności, niewłaściwe wykorzystanie dostępnych technologii, marnotrawstwo, degradacja środowiska naturalnego to tylko niektóre $\mathrm{z}$ nieetycznych zachowań, jakich efekty będą odczuwały następne pokolenia. Świadomość takich konsekwencji dla przy- 
szłych konsumentów powinna znaleźć się w zapisach omawianego dokumentu. Istotne jest, byśmy, korygując nasze obecne postępowanie i podejmując decyzje, mieli na względzie dobro przyszłych pokoleń. W analizowanym kodeksie poświęcono temu zbyt mało uwagi.

W kontekście przywołanych we wstępie słów Leszka Kołakowskiego kodeks nie jest pełny. Czy jednak powinno to być uznane za zarzut wobec analizowanego tekstu? Trudno w obliczu ciągłych zmian stworzyć coś, co będzie wyczerpywało wszystkie możliwości nieetycznego postępowania. W chwili powstania kodeksu jego twórcy zapewne odnosili się do tego, co jako nieetyczne i bezprawne miało miejsce do tej pory. Zwrócili uwagę na to, co być może szczególnie raziło, ale wpływ na dobór wskazań miał też skład zespołu opracowującego ten dokument. Byli to specjaliści reprezentujący różne środowiska. Wskazania, które wybrali, miały stać się ,punktem odniesienia do właściwych konkretnych wyborów i działań wszystkich producentów i przetwórców żywności, mając na względzie dobro i zdrowie konsumenta" (Kodeks Etyki Żywnościowej, 2013, s. 2). Może właśnie to powinno stać się powodem, dla którego producenci, przetwórcy i dystrybutorzy żywności winni przystąpić do stosowania zasad kodeksu, przecież wszyscy ostatecznie stają się również konsumentami. Czy w takim razie nie byłoby dobrze nie oszukiwać samych siebie?

Powróćmy w tym miejscu do sformułowania „dobro konsumenta”, do którego we wstępie odwołują się twórcy kodeksu. Wydaje się, że właśnie to pojęcie w sposób pełny oddaje, co każdy uczestnik łańcucha żywnościowego powinien mieć na względzie. „Dobro konsumenta” nie zostało w kodeksie jednoznacznie zdefiniowane. Jego sens i znaczenie są poniekąd intuicyjne. Niemniej jednak wszystkie wartości, do których odnosi się kodeks, tj. bezpieczeństwo, jakość, uczciwość, zaufanie, szacunek, solidarność, respektowanie prawa, odnoszą się i działają dla dobra konsumenta.

\section{Podsumowanie}

Bez względu na to, czy omawiany kodeks jest obecnie stosowany czy nie, uważam, że zasady etyczne powinny być respektowane na równi z przestrzeganiem prawa. Czy formalizacja zagadnień moralności względem żywności jest w ogóle możliwa? Trudno jednoznacznie odpowiedzieć, czy w tej formie, jaką zaproponowali twórcy kodeksu ma ona szanse powodzenia. Z pewnością wyciągnięcie wniosków byłoby trafniejsze, gdyby można było odnieść jego zapisy do późniejszej próby ich praktycznego stosowania. Niestety takich informacji nie mam.

Zwolennicy tworzenia kodeksów etycznych twierdzą, że działają one na korzyść bezpieczeństwa, pobudzają refleksyjność czy powodują wzrost zaufania (Klimczuk, 2014, s. 114). W stosunku do żywności i poszanowania konsumenta te wartości mają szczególne znaczenie, więc choćby z tego względu należałoby treść kodeksu promować i analizować. 
W przypadku żywności, niezbędnej do egzystencji człowieka i zachowania zdrowia, niemożliwy jest jakikolwiek relatywizm moralny. Ale być może wobec nieustających zmian słuszne są słowa Zygmunta Baumana, który w Etyce ponowoczesnej (2012, s. 49) pisze:

Nie istnieją nienaruszalne zasady, które można by poznać, nauczyć się ich na
pamięć i zastosować, by uciec z sytuacji bez wyjścia lub uchronić się przed po-
smakiem goryczy (czy nazwiemy go skrupułami, poczuciem winy czy grze-
chem), który przychodzi nieproszony w ślad za podjęciem decyzji i jej urzeczy-
wistnieniem. Rzeczywistość ludzka jest nieuporządkowana i wieloznaczna,
i także moralne decyzje, w odróżnieniu od abstrakcyjnych zasad etycznych, są
ambiwalentne.

Z pewnością warto bacznie przyglądać się wszelkim próbom uchwycenia w normy instytucjonalne zagadnień etycznych związanych z żywnością.

\section{Bibliografia}

Bauman, Z. (2012). Etyka ponowoczesna (J. Bauman, J. Tokarska-Bakir, tłum.). Warszawa: Wydawnictwo Aletheia.

Birnbacher, B. (1999). Odpowiedzialność za przyszłe pokolenia (B. Andrzejewski, P. Jackowski, tłum.). Warszawa: Oficyna Naukowa.

Chore krowy trafiaja do rzeźni i na nasze stoty. „Ludzie nie świnie, zjedzą wszystko. (2019). https://www.tvn24.pl/superwizjer-w-tvn24,149,m/chore-bydlokupie-chore-krowy-sprzedawane-na-mieso-w-rzezniach,903977.html

Klimczuk, A. (2014). Możliwość i użyteczność moralna kodyfikacji norm etyki zawodowej: przegląd stanowisk etycznych. Palimpsest. Czasopismo Socjologiczne, 1(6), 111-118.

Kodeks Etyki Reklamy. https://radareklamy.pl/kodeks-etyki/

Kodeks Etyki Żywnościowej. (2013). https://www.zywnosc.com.pl/wp-content/ uploads/2020/03/Kodeks_etyki_żywnościowej.pdf

Kołakowski, L. (1967). Etyka bez kodeksu. W: L. Kołakowski, Kultura i fetysze. Warszawa: Państwowe Wydawnictwo Naukowe.

Korzycka, M., \& Wojciechowski, P. (2016). Prawo żywnościowe jako nowa dziedzina prawa. Studia Iuridica Agraria, 14, 275-296. http://dx.doi.org/10. 15290/sia.2016.14.17

Kowalczyk, S. (2014). Bezpieczeństwo i jakość polskiej żywności. Roczniki Naukowe, Stowarzyszenie Ekonomistów Rolnictwa i Agrobiznesu, 16(4), 147-152.

Kryteria Żywieniowe do samoregulacji dotyczącej reklamy żywności skierowanej do dzieci w wieku poniżej 12. roku życia w Polsce. Kodeks Etyki Reklamy. Załącznik 2a. https://radareklamy.pl/kodeks-etyki/ 
Kupuj samotne banany. Za akcja w Lidlu stoją Banki Żywności. (2018). https://finanse.wp.pl/kupuj-samotne-banany-za-akcja-w-lidlu-stoja-bankizywnosci-6280063143872641a

Linek, A. (2016). Kilka słów o odżywianiu i żywności w świecie konsumpcji. W: A. Wysocki \& M. Zarzecki (red.), Etos polskich przetwórców żywności, (s. 179-208). Warszawa: Wydawnictwo Naukowe Uniwersytet Kardynała Stefana Wyszyńskiego.

List otwarty do konsumentów Fundacji Etyki Zawodowej Rolnika i Producenta Żywności „Etyczne Agro”. (2019). https://publicystyka.ngo.pl/fundacjaetyczne-agro-list-otwarty-do-konsumentow

Niklińska, N., \& Woronowski, H. (2014). Uwarunkowania etycznych postaw producentów żywności. Optium. Studia Ekonomiczne, 3(69), 156-168.

Pieńczykowska, J. (2013). Afery podkopuja zaufanie do jakości polskiej żywności. https://polskatimes.pl/afery-podkopuja-zufanie-do-jakosci-polskiej-zywnosci/ $\operatorname{ar} / 799691$

Podstawowe wymagania dotyczace znakowania żywności. (2018). https://gis. gov.pl/zywnosc-i-woda/znakowanie-zywnosci-2/

Powstał Kodeks Etyki Żywnościowej. (2013). Bezpieczeństwo i Higiena Żywności, 4, 82-83.

Raport Federacji Polskich Banków Żywności - Nie marnuję jedzenia. (2018). https://bankizywnosci.pl/wp-content/uploads/2018/10/Przewodnik-do-Ra portu_FPBZ_-Nie-marnuj-jedzenia-2018.pdf

Rolnictwo ekologiczne $w$ skrócie. Komisja Europejska. https://ec.europa. eu/agriculture/organic/consumer-trust_pl

Spaemann, R. (2006). Granice. O etycznym wymiarze działania (J. Merecki, tłum.). Warszawa: Oficyna Naukowa.

Wojciechowski, T. (2012). Człowiek czy ekonomia? Bezpieczeństwo i Higiena Żywności, 3, s. 10

Wysocki, A. (2016). Podstawowe zasady etyki w biznesie żywnościowym. W: A. Wysocki, \& M. Zarzecki (red.), Etos polskich przetwórców żywności (s. 53-67). Warszawa: Wydawnictwo Uniwersytetu Kardynała Stefana Wyszyńskiego.

Wysocki, A., \& Zarzecki, M. (2016). Etos zawodowy a współczesne problemy produkcji żywności. W: A. Wysocki, M. Zarzecki (red.), Etos polskich przetwórców żywności (s. 9-22). Warszawa: Wydawnictwo Uniwersytetu Kardynała Stefana Wyszyńskiego. 